\title{
Contrastive Analysis of Discourse Representation in Indonesia Newspaper (Kompas) and English Newspaper Reports (Jakarta Post)
}

\author{
Syafryadin \\ University of Bengkulu \\ Syafryadin@unib.ac.id
}

\begin{abstract}
Discourse representation deals with language structures which has crucial role not only for the text, but also for social practices. Newspaper is one of the real implementations of discourse representation because newspaper comprises several components in discourse representation. Newspaper in every country is made based on its language and every newspaper has difference and similarity in terms of discourse representation. Therefore, this study aimed to investigate the contrastive analysis of discourse representation in Indonesia newspaper and English newspaper reports. The subjects of this study were KOMPAS as representative of Indonesia newspaper and Jakarta Post as representative of English newspaper. This present study applied descriptive qualitative design which focused on representing verbs and modes of discourse representation (direct and indirect discourse). The findings of this study were that both newspapers have differences and similarities even though the difference was not quite dominant. The similarity of these newspapers could be seen from the use of reporting verbs and indirect discourse which were more dominant than the other parts in discourse representation. The difference could be seen also from representing verbs and modes of discourse representation. Although, reporting verbs are majority parts in Indonesia newspaper and English newspaper, but several words in Indonesia had the same translation into English. Manner of speaking verbs, mental verbs were still rare found in Indonesia newspaper. In Indonesia newspaper had only direct and indirect discourse, while in English newspaper had direct, indirect, free direct discourse, and indirect discourse in headline. In short, these newspapers have contrastive analysis in terms of discourse representation.
\end{abstract}

Keywords: Contrastive Analysis, Discourse Representation. 


\section{INTRODUCTION}

Discourse representation is one of the parts in discourse which has important role in analyzing the text of news reports. Discourse Representation Theory (DRT) is a formal semantic model of the processing of text in context which has applications in discourse understanding. DRT was originally formulated in (Kamp, 1981) and further developed in (Kamp \&Reyle, 1993), with a concise technical summary in (van Eijck\& Kamp, 1997). DRT grew out of Montague's model-theoretic semantics (Thomason, 1974) which represents the meanings of utterances as logical forms and supports the calculation of the truth conditions of an utterance. DRT addresses a number of difficulties in text understanding (e.g. anaphora resolution) which act at the level of the discourse.

Many newspapers have discourse representation based on the language used in the newspapers. This researcher uses Indonesian newspaper and English newspaper reports because the researcher wants to see the comparison of Indonesia newspaper reports and English newspaper reports in terms of discourse representation. However, the researcher takes Kompas newspaper as the representative of Indonesian newspaper and the Jakarta Post newspaper as representative of English newspaper because those newspapers are always read by most of Indonesian. Furthermore, many Indonesian have difficulties in order to identify the differences and similarities of the newspapers in terms of discourse representation. For example, in finding representing verbs and modes of discourse representation, such as direct and indirect discourse, most of students or Indonesian are still hard to do it.

Several studies conducted research on contrastive analysis such as He and Zhou (2015) about Contrastive analysis of Lexical choice and Ideologies, Fortunio-Balles (2016) about a contrastive analysis of the discourse marker then in english and spanish lectures, Mohseni\& (2015) about analysis of contrastive Discourse markers Implementation in ESP Books, Faridah and (2018) about contrastive analysis of expression on japanese and indonesian love lyrics, Rafatbaksh and Jafari (2015) about Contrastive analysis of Discourse Representation in Persian and English online newspapers, Debbagh, (2012) which aimed at analysing discourse representations of women in Arabic television news on the two main Moroccan television channels, Junaidi (2015) about Representation Power in class discourse and Asrianti (2019) about power Representation in discourse analysis at junior high school. 
In accordance with the previous studies, most of the researches about contrastive analysis, but not in discourse representation. Only one research was in relation to contrastive analysis of discourse representation, but the subject was Persian, English online Newspaper and news broadcast. Moreover, most of the researches just focused on lexical choice, ideologies, discourse markers, power representation, and expression. Besides, most of the previous studies used qualitative. The dissimilarities of the current research with the previous researches were the focus, an object and the research methodology. The current research is about discourse representation in Jakarta Post and Kompas Newspaper in Indonesia. However, the previous study used Persian and Online English Newspaper (New York Times). Then, the previous study only focused on the representing verbs, but, the current research added the modes of the representation. The current research used qualitative design which implemented thematic analysis, while the previous studies just used the coding.

Based on the explanation above, the researcher conducted the research on discourse representation in order to see the differences and similarities of those newspapers. For more details, this research had three aims namely (1) to identify representing verbs Indonesian newspaper report and English newspaper reports in terms of discourse representation (2) to identify modes of discourse representation in Indonesian newspaper report and English newspaper reports in terms of discourse representation And (3) to identify similarities and differences between Indonesian newspaper report and English newspaper reports in terms of discourse representation?

\section{THEORETHICAL FRAMEWORK}

The framework of critical discourse analysis has been used in analyses of the news discourse. Fairclough (1992) describes the concept of discourse representation, wherein there is a form of intertextuality in which parts of other texts are taken into a text marked with devices such as quotation marks and reporting clauses. Fairclough (1992) points out that discourse representation is associated with not only language texts but also social practices. That is, it is important to analyze intertextuality or discourse representation from both linguistic and social perspectives.

\section{Representing Verbs}

The choice of the representing verb is closely associated with the extent to which represented discourse is controlled by representing 
discourse. Various kinds of representing verbs are used in the news report. They can be divided into the following categories:

1. reporting verbs ("say", "tell"): The reporter gives a neutral evaluation of represented discourse. The represented discourse is not controlled by the reporter. It is presented to the reader objectively.

2. mental (thought) verbs ("wonder", "recall"): The internal states of the subject of represented discourse is presented to the reader. These verbs are not frequently used in the newspaper report to represent discourse. Unlike prose fiction, the actual spoken discourse of a news source is transformed into the reporter's written discourse in the news report (Short, Semono\& Culpepper, 1996).

3. manner-of-speaking verbs ("shout"): Physical characteristics are given to represented discourse and presented to the reader.

4. speech act (illocutionary) verbs ("warn", "claim"): Illocutionary force is given to represented discourse by the reporter. Thus, the reader's interpretation of the represented discourse is controlled by the reporter. However, each of these speech act verbs has a different kind of illocutionary force.

\section{Modes of Discourse Representation}

There are forms of direct and indirect discourse representation. Classifying the modes of discourse representation is closely associated with the degree to which represented discourse is demarcated from representing discourse.

Direct Discourse Representation

a. direct discourse

Direct discourse consists of a reported clause and a reporting clause. The speech act value of the reported clause is basically maintained in direct discourse. The reported clause is a verbatim report of the original utterance although there are some exceptions. Also, there is a clear demarcation between the reported clause and the reporting clause.

b. direct discourse (slip)

There is a case in which indirect discourse slips into direct discourse. In this case, the represented discourse is partially a verbatim report of the original utterance. This case can also be included in the mode of direct discourse (Fairclough, 1995). 


\section{c. Free direct discourse}

There is no reporting clause. However, the reported clause and quotation marks are retained. The reported clause is basically a verbatim report of the original utterance. No speech act value is added to the reported clause. Thus, the reader has direct access to the represented discourse.

Indirect Discourse Representation

a. Indirect discourse

This form of discourse consists of the reporting clause and the reported clause. No quotation marks are used. It is clear whose voice is represented. The represented discourse could be a verbatim report of the original utterance. However, the original utterance of the represented discourse is generally summarized or paraphrased. Thus, the reader doesn't have direct access to the represented discourse.In addition, there are cases in which the phrase, "according to" and the colon, " : " are used to show whose voice is represented. In these cases, no representing verbs are used. These cases could be included in the category of indirect discourse.

b. free indirect discourse (unsignaled form of discourse representation)

In free indirect discourse, there are no quotation marks. There is a mixing of representing discourse and represented discourse. There is no clear demarcation between the representing discourse and the represented discourse. Thus, discourse representation is double-voiced. This mode covers a broad range of discourse representation. Toolan (1988) suggests that free indirect discourse has the following characteristics:

- The third-person pronoun is used in presented discourse.

- Modality markers (must, had to, could, would, might) are frequently used for presented discourse to express stance about probability and obligation. Interpretation is given to presented discourse.

- This form has a summarizing effect, and the reader doesn't have direct access to the original utterances of represented discourse.

In addition, there are similarities between free indirect discourse and free direct discourse as follows:

- There is a case in which no setting is presented. Thus, it is not clear whose voice is represented. 
- In presented discourse, there is syntactic inversion in question format. The subject and the verb are inverted. Also, presented discourse is in a colloquial style.

- This form functions as highlighting represented discourse and presenting it to the reader.

Narrative Speech Act (Unsignaled Form of Discourse Representation)

Short et al. (1996) have developed this category of discourse representation. The function of this form is similar to that of free indirect discourse. There is a mixing of representing discourse and represented discourse. There is no separate reported clause. This form shows that the speech act is performed by a character in a newspaper report. The speech act value of the original utterance is presented by the reporter. Then, presented discourse is most controlled by the reporter. The reader doesn't have access to what the character actually said. Also, this form has a clear summarizing effect.

\section{RESEARCH METHODOLOGY}

\section{Design of the Study}

This study applied descriptive Qualitative design which used the contrastive analysis that aimed to know what are the differences and similarities of discourse representation in Indonesia newspaper and English newspaper reports.

\section{Source of the Data}

The sources of the data are Indonesia newspaper and English newspaper reports. KOMPAS is as the representative of Indonesia newspaper and Jakarta Post is as the representative of English newspaper.

\section{Procedure of Data Collection}

Collected the newspaper from Kompas (Indonesia newspaper) and Jakarta Post (English newspaper).

Decided and read the parts of discourse representation as an object of the study.

- Underlinedthe discourse representation in both newspapers.

- Identified the representing verbs and modes of discourse representation.

\section{Technique of Data Analysis}

The gathered data were qualitatively by following the steps: 
- Doing classification of the data based on representing verbs and discourse representation.

- Making description and generalization of every data in terms of representing verbs and discourse representation.

- Finding out similarities and difference among the newspapers in terms of discourse representation

\section{FINDINGS}

Representing verbs in Indonesian newspaper report (KOMPAS) and English newspaper (Jakarta Post).

(1) Representing verbs In Indonesian Newspaper report

(a) Use of representing verbs in direct discourse

Tabel 1.

Representing Verbs in Direct Discourse

\begin{tabular}{|c|c|c|c|c|c|}
\hline $\begin{array}{c}\text { Reporting } \\
\text { verbs }\end{array}$ & Total & $\begin{array}{c}\text { Speech act } \\
\text { verbs }\end{array}$ & Total & $\begin{array}{c}\text { Mental } \\
\text { verb }\end{array}$ & Total \\
\hline Papar & 5 & Tambah & 2 & Percaya & 1 \\
Ujar & 72 & Cerita & 1 & & \\
Ucap & 2 & Terang & 1 & & \\
Kata & 96 & & & & \\
Katanya & 30 & & & & \\
Tulis & 3 & & & & \\
Jawabnya & 2 & & & & \\
Tuturnya & 10 & & & & $\mathbf{1}$ \\
Lanjutnya & 3 & & $\mathbf{4}$ & & \\
\hline Total & $\mathbf{1 7 3}$ & & & & \\
\hline
\end{tabular}

Based on the table 1, it can be seen that in direct discourse, it is dominated by reporting verbs. It showed that the writer or reporter of Indonesia newspaper report wants to show the news is directly gotten from news source. Furthermore, there are also mental verb and speech act verb. However, the mental verb is the most minorities in this newspaper. The total of reporting verbs is 173 , speech verb is 4 and mental verb is 1 . In reporting verbs, it is dominated by "kata".

(b) Use of representing verbs in indirect discourse

Tabel 2.

Representing Verbs Indirect Discourse 


\begin{tabular}{|c|c|c|c|c|c|}
\hline $\begin{array}{c}\text { Reporting } \\
\text { verbs }\end{array}$ & Total & $\begin{array}{c}\text { Speech act } \\
\text { verbs }\end{array}$ & Total & $\begin{array}{c}\text { Mental } \\
\text { verb }\end{array}$ & Total \\
\hline Mengatakan & 78 & Berkomitmen & 1 & Meyakini & 5 \\
\hline Menjelaskan & 7 & Menuntut & 1 & $\begin{array}{c}\text { Mengapresi } \\
\text { asi }\end{array}$ & 1 \\
\hline $\begin{array}{c}\text { Menyampai } \\
\text { kan }\end{array}$ & 6 & Berpendapat & 6 & Mengagumi & 1 \\
\hline Mengusulkan & 1 & Membenarkan & 1 & & \\
\hline Menuturkan & 9 & $\begin{array}{c}\text { Mengampanye } \\
\text { kan }\end{array}$ & 1 & & \\
\hline Mengajukan & 2 & menegaskan & 4 & & \\
\hline $\begin{array}{c}\text { Mengungkap } \\
\text { kan }\end{array}$ & 12 & Menambahkan & 7 & & \\
\hline Menyatakan & 6 & Menuding & 2 & & \\
\hline $\begin{array}{l}\text { Mengemuka } \\
\text { kan }\end{array}$ & 1 & Berharap & 1 & & \\
\hline \multirow{6}{*}{$\begin{array}{l}\text { Mengumum } \\
\text { kan }\end{array}$} & 1 & & 3 & & \\
\hline & & Menkonfirmasi & 1 & & \\
\hline & & Mendesak & 1 & & \\
\hline & & Mengakui & 5 & & \\
\hline & & Menilai & 3 & & \\
\hline & & Meminta & 2 & & \\
\hline Total & 127 & & 39 & & 7 \\
\hline
\end{tabular}

Based on the table 2, it can be seen that in indirect discourse, it is dominated by reporting verbs. It showed that the writer or reporter of Indonesia newspaper report wants to show the news is directly gotten from news source. The total of reporting verbs is 127 , speech verb is 39 and mental verb is 7 . However, speech verb is more dominant than mental verb. In reporting verbs, it is dominated by reporting verb of "mengatakan", while in speech verb, it is dominated by "berpendapat" and mental verb is "meyakini".

(2) Representing verbs In English newspaperNewspaper report

(a) Use of representing verbs in direct discourse

Tabel 3.

Representing Verbs in Direct Discourse

\begin{tabular}{|c|c|c|c|c|c|c|c|}
\hline $\begin{array}{c}\text { Reporting } \\
\text { verbs }\end{array}$ & Total & $\begin{array}{c}\text { Speech } \\
\text { act }\end{array}$ & Total & $\begin{array}{c}\text { Mental } \\
\text { verb }\end{array}$ & Total & $\begin{array}{c}\text { Manner } \\
\text { of }\end{array}$ & Total \\
\hline
\end{tabular}




\begin{tabular}{|c|c|c|c|c|c|c|c|}
\hline & & verbs & & & & $\begin{array}{c}\text { Speakin } \\
\text { g }\end{array}$ & \\
\hline Said & 183 & Joked & 2 & & & Thanked & 2 \\
Told & 15 & & & & & & \\
saying & 1 & & & & & & \\
Continues & 3 & & & & & & \\
Stated & 2 & & & & & & \\
Says & 15 & & & & & & \\
\hline Total & $\mathbf{2 1 9}$ & & $\mathbf{2}$ & & $\mathbf{0}$ & & $\mathbf{2}$ \\
\hline
\end{tabular}

Based on the table 3, it can be seen that in direct discourse, it is dominated by reporting verbs. It showed that the writer or reporter of Indonesia newspaper report wants to show the news is directly gotten from news source. Furthermore, there are also manner of speaking verb and speech act verb. However, the mental verb does not exist in this newspaper. The total of reporting verbs is 219 , speech verb is 2 and manner of speaking verb is 2 . In reporting verbs, it is dominated by "said".

(b) Use of representing verbs in indirect discourse

Tabel 4.

Representing Verbs in Indirect Discourse

\begin{tabular}{|c|c|c|c|c|c|}
\hline $\begin{array}{c}\text { Reporting } \\
\text { verbs }\end{array}$ & Total & $\begin{array}{c}\text { Speech act } \\
\text { verbs }\end{array}$ & Total & $\begin{array}{c}\text { Mental } \\
\text { verb }\end{array}$ & Total \\
\hline Said & 121 & Dismissed & 1 & Expressed & 3 \\
Told & 10 & Voiced & 1 & Knew & 1 \\
Added & 12 & Denied & 2 & Believe & 3 \\
Command & 1 & Assured & 2 & & \\
Shared & 2 & Claimed & 3 & & \\
Adding & 10 & Stressed & 3 & & \\
Revealed & 1 & Stated & 2 & & \\
Reported & 3 & Issued & 1 & & \\
Announced & 4 & Admitted & 1 & & \\
Pointed out & 3 & Hinted & 1 & & \\
Explained & 3 & Showed & 2 & & \\
Declared & 1 & Insists & 1 & & \\
Noted & 5 & Suggested & 2 & & \\
Says & 10 & Maintained & 2 & & \\
& & Expected & 1 & &
\end{tabular}




\begin{tabular}{|l|c|c|c|c|c|} 
& & Concluded & 1 & & \\
& & Argued & 1 & & \\
& & Planned & 1 & & \\
& & Agreed & 1 & & \\
& & Warned & 1 & & \\
& & Reminisced & 1 & & \\
\hline Total & $\mathbf{1 8 6}$ & & 1 & & $\mathbf{7}$ \\
\hline
\end{tabular}

Based on the table 4, it can be seen that in indirect discourse, it is dominated also by reporting verbs. It showed that the writer or reporter of Indonesia newspaper report wants to show the news is indirectly gotten from news source. The total of reporting verbs is 186 , speech verb is 32 and mental verb is 7 . However, speech verb is more dominant than mental verb. In reporting verbs, it is dominated by reporting verb of "said". Related to the table, it can be seen that the newspaper consists of several kinds of reporting verb, speech act verbs and mental verbs, but the kinds of speech act verbs are more varieties than reporting verbs. Even though, the total number of reporting verbs is more dominant than speech act verbs.

Forms of Discourse Representation in Indonesian newspaper report (KOMPAS) and English newspaper (Jakarta Post).

(1) Forms of Discourse Representation in Indonesian Newspaper (KOMPAS)

(a) "Komandan Korem sudah turun kelapangan. Polisi militer menjaga kesatrian Yonif sehingga tak ada yang meninggalkan tempat. Sebaliknya, Provos Polri juga menjaga markas Brimob." Kata Fuad Rasya.

(Direct discourse in the body)

The sentence above is categorized as direct discourse because the sentence consists of three clauses and there are reporting clause and reported clause. The quotation marks are also retained in the sentence. The sentence uses neuter reporting verb "said" to indicate the speaker wants to say.

(b) Mereka meyakini berawal dari generasi muda, persatuan Indonesia masih punya harapan.

(Indirect discourse) 
The sentence above is indirect discourse because there is no quotation mark. However, the sentence contains unclear voice because the reader is difficult to find out who are "they". Therefore, the objectivity is not quite represented in the sentence. Furthermore, there is a mental verb namely "meyakini" that has function to convince the reader about what they want to believe.

(2) Forms of Discourse Representation in English Newspaper (Jakarta Post)

(a) "The soldier are firing at us. We are surrounded," said Soerya.

(Direct discourse in the body)

The sentence above is called as direct discourse because there are reporting and reported clause. Quotation marks are retained. The voice is very clear in the sentence. Thus, the objectivity of the represented discourse is maintained. In this case, the reporter represents discourse from the direct news source. Also, the neutral reporting verb "said" is used. As a result, more objectivity and independence are given to the represented discourse.

(b) "it is not something we like to see ..... we call on occupiers to stick form to peaceful and non-violent principles and be responsible participant of umbrella movement," said 21-year-old Lester Shum of the Hongking Federation of Students.

(Direct Discourse in the body)

The sentence above is also categorized as direct discourse although there is a part that has been omitted in the sentence. It is because the sentence still has clear reporting and reported clause. Then, the writer also still uses neuter reporting verb namely "said". The information is directly gotten from direct news source.

(c) "it will also enable further cooperation in a wide range of areas, such as infrastructure, food security and sustainable forestry management."

(Free direct discourse in the body)

This is a case in which the reporting clause doesn't exist, and where quotation marks are thus retained. It is not clear whose voice is represented although it can be inferred from the context of the text. This form of free direct discourse is used to highlight the mental and emotional aspects of a person in a news story and bring his or her past experience to the present in a style of monologue. 
(d) A microbiologist claimed on Wednesday during his testimony at the South Jakrta District Court that there was no indication of herpes in any of the medical examination results of a six-year-old-boy who was allegedly abused at the Jakarta International School earlier this year.

(Indirect discourse in the body)

The sentence above is indirect discourse because there is no quotation mark. Reporting clause and reported clause still exist in the sentence. In this case, the voice is also clear. Then, there is "claimed" as speech act verb which gives illocutionary force to represented discourse by the reporter. Thus, the reader's interpretation of the represented discourse is controlled by the reporter. However, each of these speech act verbs has a different kind of illocutionary force.

(e) Indonesia: Following the fourth round of evacuations of Indonesian national from a chaotic Yemen in a month, the foreign ministry insists that it has no plans to close the Indonesian embassy in Sana'a or relocate their Yemeni operations to another country.

(Indirect discourse in the headline)

The sentence above is also categorized as indirect discourse even though it is not canonical forms of indirect discourse. The sentence has also speech act verb "insists" which has illocutionary force that will be given to the represented discourse.

Total numbers of Direct discourse and indirect discourse in KOMPAS and Jakarta Post

Table 5.

Total numbers of Direct discourse and indirect discourse in KOMPAS and Jakarta Post

\begin{tabular}{|c|c|c|c|}
\hline KOMPAS & Total & Jakarta Post & Total \\
\hline Direct Discourse & 263 & Direct Discourse & 235 \\
Indirect & 286 & Indirect Discourse & 277 \\
Discourse & & $\begin{array}{c}\text { Free Indirect Discourse } \\
\text { Indirect Discourse in } \\
\text { headline }\end{array}$ & $\begin{array}{c}53 \\
11(64)\end{array}$ \\
\hline Total & 594 & & 576 \\
\hline
\end{tabular}




\section{Contrastive Analysis of Forms and Overall Use of Discourse Representation}

In Indonesian newspaper (KOMPAS) and English newspaper (Jakarta Post) have similarities and differences. The first, the similarity of Indonesian newspaper and English newspaper frequently used form of indirect discourse because the forms or structures of language between Indonesia and English are similar namely subject, predicate, object, and complement. Besides, this form of discourse consists of the reporting clause and the reported clause. No quotation marks are used. It is clear whose voice is represented. The represented discourse could be a verbatim report of the original utterance. However, the original utterance of the represented discourse is generally summarized or paraphrased. Thus, the reader doesn't have direct access to the represented discourse. Furthermore, the use of reporting verbs are also frequently used in Indonesia newspaper and English newspaper rather than speech verbs because the reporter gives a neutral evaluation of represented discourse. The represented discourse is not controlled by the reporter. It is presented to the reader objectively.

The second, the differences of Indonesian newspaper and English newspaper can be seen from representing verbs and modes of discourse representation. In terms of representing verbs, even though those representing verbs are dominated by reporting verbs, but in Indonesia, several reporting verbs have the same translation into English for example, ujar, ucap, kata can be "say or said". Besides, the speech act verbs in English newspaper is more dominant that in Indonesia newspaper. The speech act verbs are used to give illocutionary force to the represented discourse. In term of modes of discourse representation, in Indonesia newspaper was only found direct discourse and indirect discourse, while in English newspaper, modes of direct and indirect discourse are more varieties namely direct, indirect, free direct discourse, indirect discourse in headline and etc.

\section{DISCUSSION}

Indonesian newspaper (KOMPAS) and English newspaper (Jakarta Post) are almost similar in terms of discourse representation because Indonesian language and English have the same structures. However, the differences can appear at looking the representing verbs and forms of discourse representation. All in all, indirect discourse has the largest portion in this issue that happens to those newspapers. The speech act verbs, mental verbs and manner of speaking exist in the 
newspaper. Even though the portion or the numbers of speech act verbs are less than indirect discourse, but the speech act verbs are more varieties than reporting verbs. According to Fairclough (1992), illocutionary force is given to represented discourse by the reporter and discourse representation is not only related to the whole text, but also for social practices. In other words, how can the discourse representation be applied in daily life or daily activity either academic or non academic. Then, the use of discourse representation in newspapers is one of the implementation of the theory of discourse representation itself. In addition, Fairclough (1992) discourse representation consists of representing verbs and modes of discourse representation. Representing verbs include reporting verbs, mental verb, manner of speaking verb and speech act verb. Modes of discourse representation involve direct discourse representation (direct discourse, direct discourse (slip), and free direct discourse) and indirect discourse representation (indirect discourse and free indirect discourse). Related to these parts from discourse representation, Indonesian newspaper (KOMPAS) only had direct and indirect discourse and some representing verbs, but English newspaper (Jakarta Post) has direct and indirect also with some additional parts like free direct discourse and indirect discourse in the headline. English newspaper also had several representing verbs like reporting verbs, mental verbs, manner of speaking verbs, and speech act verbs. In brief, in terms of discourse representation, English newspaper is more complete than Indonesian newspaper.

\section{CONCLUSION}

Based on the findings of this study, it can be concluded that the Indonesian newspaper and English newspaper are more dominated by indirect discourse. Besides, those newspapers also comprised several representing verbs, such as reporting verbs, mental verbs, manner of speaking verb and speech act verb. However, those newspapers have also differences in terms of modes of discourse representation because in Indonesian newspaper only had direct and indirect discourse, while in English newspaper could be more complete like free direct discourse and indirect discourse in the headline. Therefore, English newspaper (Jakarta Post) provided various modes of discourse representation than Indonesian newspaper (KOMPAS). Based on this study, it can be recommended for further research to develop the object of the newspapers. Besides, it can be also focused on other points in discourse representation. 


\section{REFERENCES}

Asrianti. (2019). RepresentasiKekuasaandalamWacana Kelas di Sekolahmenengahpertama. RETORIKA. Jurnal Bahasa, sastra dan pengajarannya. Vol. 12 (1). Pp. 14-24.

Debbagh, Mohammed. (2012). Discourse analysis of the representations of women in Moroccan broadcast news. The Journal of North African Studies. Vol. 17 (4). Pp. 653-670.

Fairclough, N. (1992). Discourse and Social Change. Cambridge: Cambridge University Press.

Fairclough, N. (1995). CriticalDiscourse Analysis. London: Longman.

Faridah, S and Kusumawati, M. (2018). Contrastive analysis of Expression on Japanese and Indonesian Love Lyrics. JAPANEDU: Jurnalpendidikan dan Pengajaran Bahasa Jepang. Vol. 3 (2), pp. 85-94.

Fortunio-Balles, Begona. (2016). Academic Discourse Markers: A contrastive Analysis of the Discourse Marker then in English and Spanish Lectures. Research gate. Pp. 57-78 https://www.researchgate.net/publication/305387252

He, Xianzhong and Zhou, Xulu. (2015). "Contrastive analysis of Lexical choice and Ideologies in News Reporting the Same Accidents between Chinese and American". Theory and Practice in Language Studies, Vol. 5 (11). Pp. 2356-2365.

Junaidi. (2015). "Repersentation Power in Class Discourse: A Study of Communication Ethnography”. JurnalIlmu Pendidikan. Vol.12 (3). Pp. 1-11.

Kamp, H. (1981). A theory of truth and semantic representation. In Groenendijk, J., Janssen, T., \&Stokhof, M. (Eds.), Formal methods in the study of language, No. 135, pp. 277\{322. Mathematical Centre, Amster-dam.

Kamp, H., \&Reyle, U. (1993). From discourse to logic: Introduction to model theoretic semantics of natural language, formal logic and discourse representation theory. Kluwer Academic Press, Dordrecht, the Netherlands.

Mohseni, A., \&Golestani, M. (2015). Analysis of Contrastive Discourse markers Implementation in ESP Books of Coumputer Science Developed by Non-Native (Iranian) and Native (British) Authors. Journal of Applied Linguistics and Language Research. Vol. 2 (6). Pp. 128-144. 
Rafatbaksh, E and Jafari, S. (2015). "Contrastive analysis of Discourse Representation in Persian and English online newspapers: Reports on Iran's Nuclear Program". International Journal of English and Education. Vol. 4 (3). Pp. 81- 91.

Short, M., Semino, E., and Culpeper, J. (1996). Using a corpus for stylistics research: speech and thought representation. In J. Thomas and M. Short (Eds.), Using Corpora forLanguage Research, (pp. 110-31). New York: Longman.

Thomason, R. (1974). Selected papers of Richard Montague. Yale University Press, New Haven, CT.

Toolan, M. (1988). Narrative: Critical Linguistic Introduction. UK: Routledge.

Van Eijck, J., \& Kamp, H. (1997). Representing Discourse in Context. In van Bethem, J., \&terMeulen, A. (Eds.), Handbook of logic and language, pp. 179\{237. Elsevier Science B.V., New York. 